\title{
Design, Construction \& Testing Of Two Wheel Drive Forklift
}

\author{
Dr. Pravin Potdukhe, \\ Department of Mechanical Engineering, RCERT Chandrapur, Maharashtra ,India, \\ pravinpotdukhe1@rediffmail.com
}

\begin{abstract}
Mechanical forklift is an improved, cheap \& advance technology that brings revolution in the material handling division of a factory, warehouses and distribution centers. In designing a drive-in system, dimensions of the fork truck, including overall width and mast width, must be carefully considered. The forklift available in the market is costly. But the present design is cheap \& is battery operated. The aim of the project was to transfer the goods and raw materials from one place to another with minimum cost \& safety. After the completion of manufacturing operations and assembly of fork lift, a trial run was taken and performance was satisfactorily completed. It can easily lift load up to $250-300 \mathrm{~kg}$ for about height of $1.8 \mathrm{~m}$
\end{abstract}

Keywords - Fork lift, industrial truck

\section{INTRODUCTION}

A forklift is a vehicle which resembles a small truck that has two metal forks on the front $\&$ is used to lift the load. The operator drives the forklift forward until the forks is pushed under the cargo and can then lift the cargo at specified height in the air by operating the forks. The forklift reduces the time consumption and increases the workflow with less number of risks like careless material handling, material damage, and injury to labour etc. A two wheel drive forklift is a powered industrial truck used to lift and move materials at short distances.

The forklift was developed in the early 20th century by various companies including the transmission manufacturing company Clark and the hoist company Yale \& Towne Manufacturing. A two wheel drive lifting device is used to minimize the hazards associated with materials handling operations; some examples include cranes, hoists, lift trucks, scissor lifts, lift tables and forklifts. These devices must be operated, maintained and regularly inspected by competent individuals only. Typically, lifting devices are used to handle these loads. There are many different types of lifting devices available; selection of the most appropriate one depends on factors such as the characteristics of the load, where the load needs to be moved, the general work environment and the training and skills of the operator. The loads handled by these devices tend to be heavy or large and awkward and therefore there are inherent safety concerns associated with lifting devices.

\section{LITERATURE SURVEY}

The different type of fork lifting equipment depending upon the design functioning mentioned in references 1 to 4are:

1. Hand pallet truck - no onboard power system of any kind; the operator's muscle power is used to jack-up and move loads.

2. Electric counterbalanced truck

3. Internal Combustion Engine Powered Counterbalanced Forklift

4. Electric forklifts - powered by lead-acid batteries or sometimes lithium-ion batteries,

5. Fuel cell forklifts are often used in refrigerated warehouses as their performance is not degraded by lower temperatures.

\section{DESIGN \&WORKING PRINCIPLE}

Forklifts are rated for loads at a specified maximum weight and a specified forward center of gravity. It's imperative that these structures be designed to accommodate their efficient and safe movement. The basic working principle behind the two wheel drive forklift machine is same as that of a lift technology i.e. conversion of rotary motion into sliding motion (i.e. upward or downward). The wire rope is used to for conversion of rotary motion to lift up. A pulley drum is attached to chain block which is controlled by a D.C. Motor. The wire rope is mounted on the drum in which one end of rope is fixed on the drum and other side is fixed to the fork mechanism which converts the rotary motion of motor into lifting motion of fork. The chain block helps in gaining the initial to torque while lifting the load. Fig 1 represents the block diagram of lifting mechanism.

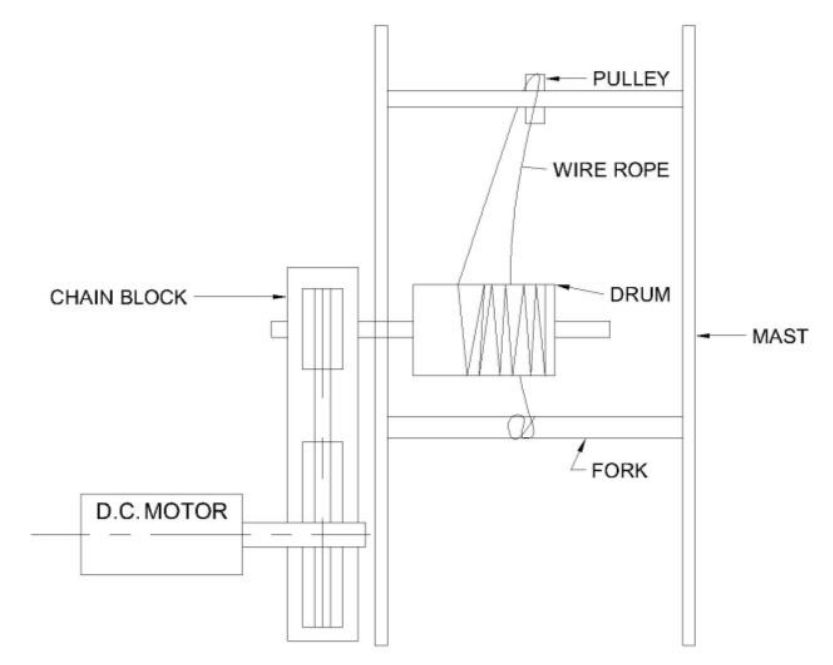

Figure 1. Block diagram of lifting mechanism.

\section{COMPONENTS DESCRIPTION}

The assembled two wheel drive forklift using battery as power source is shown in figure 2. Different components used in the forklift are as given below:-

a.Base (Chassis) :

The chassis is fabricated from Plywood sheet. This is done for ease of fabrication, and to reduce the overall weight. The 
chassis was designed to take a static load of $3 \mathrm{~kg}$. The flange which holds the motor was designed using aluminium and is bolted to the chassis so that the driving motors can easily accommodate below the chassis. The chassis incorporates hole for attaching front wheel, rear trolley wheels and also for attaching the lift structure (mast).

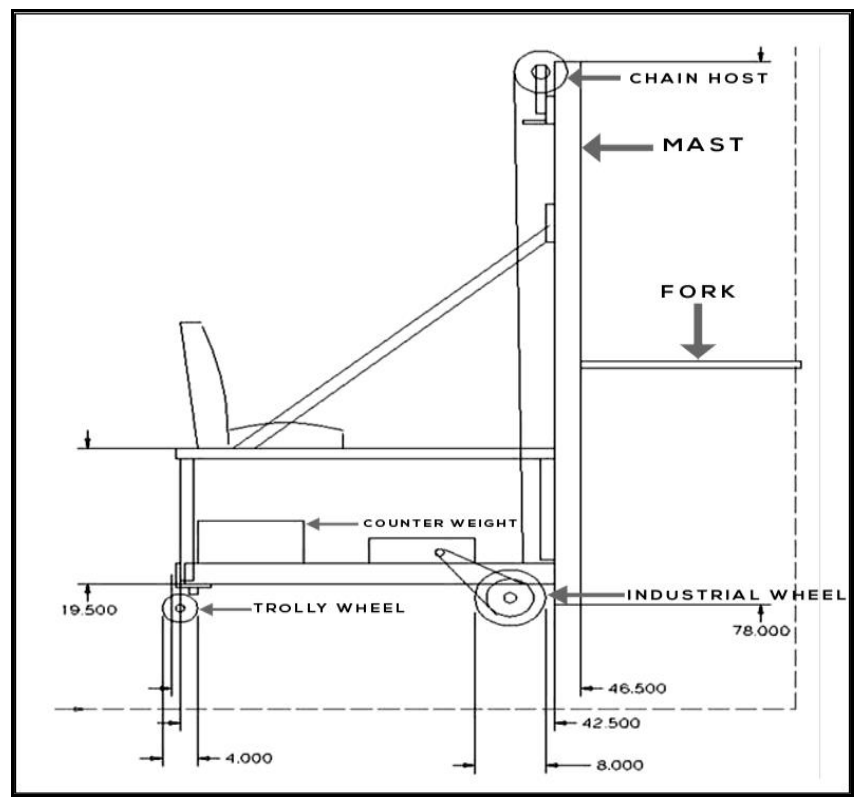

Figure 2. Two wheel drive forklift

b.Remote Controlled System :

The forklift is equipped with 6 manual keys. By activating these keys manually, all the movements can be created in the forklift. All these 6 keys are directly interfaced with electrical bridge circuit at input side, one end of all the keys are shorted together and connected to the ground. When any key is pressed, biased current is transmitted to the next node and follows, based on this bias the circuit drives the motor. This system is devised from principles provided in references $5 \& 6$ c.Slider :

Its a rectangular plate which is held between two vertical channels of aluminium which are free to slide up and down to lift and lower the weight/load up to a desired limit with the help of rope which is connected to the DC Motor by means of Shaft and Bevel gears.

d.Fork

It is a cantilevered arms attached to the frame and mast for lowering and raising the carriage load. It is the principle working part that directly deals with the working load.

e.Mast :

The mast is the vertical support that permits raising and lowering the carriage load. The carriage load is lifted and lowered using the fork and lifting mechanism assembled on the mast. The mast also acts as a part of frame. The mast is designed by considering the maximum load that is to be lifted by the fork i.e. load acting on it and the height up to which the load is to be lifted. The manufacturing process includes welding, grinding, drilling, cutting etc.

\section{f. DC Motor :}

The DC Motor is the driving power provided for the movement in forward and reverse direction. The DC Motor used has the rated input of 24 volts, 350 watt, each individual front wheels has separate motors.

g. Chain Block :

The chain block is connected to DC Motor to lift the load. The chain block help in gaining the initial torque which reduces the vibrations or jerk while lifting and reduces the chance of failure..

\section{h. Battery :}

It supplies power to motor and gear box which runs the wheel and barrel. 12 volt battery is used to supply power.

i. Other components

1) Axle or the frame of the forklift.

2) Switch: - 2 way switch

This switch is used for selecting direction of fork lift.

\section{STRESS ANALYSIS (ANSYS) OF TWO WHEEL DRIVE FORK LIFT}

The basic calculations needed were calculated \&verified from references 7-9. Further the stress analysis was carried out by using Ansys using fork Dimensions -Thickness $=25 \mathrm{~mm}$, Length $=60 \mathrm{~cm}$, Breadth $=8 \mathrm{~cm}$

The frame was designed for three conditons

1. Considering fork as a cantilever beam \& a point load acting at the end of the beam. Using material SAE 1030 , maximum allowable bending stress $=225 \mathrm{Mpa}$

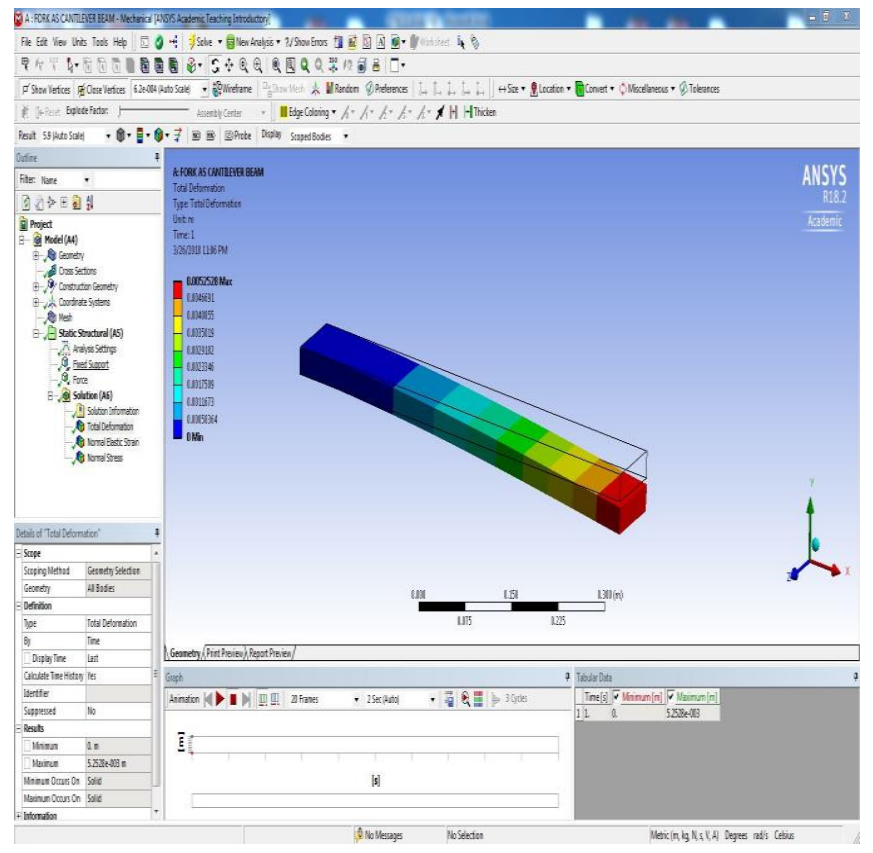

Young Modulus = 204gpa,Poisson's Ration= 0.3, Load Lifted $150 \mathrm{~kg}(1470 \mathrm{~N})$.

Figure 3. Stress analysis (ansys) of fork lift (cantilever beam $\&$ a point load)

By using Ansys software, Figure 3, bending stress = 113.55 Mpa,

Allowable Stress > applied stress

Design is safe with factor of safety $1.98 \&$ total deformation $5.25 \mathrm{~mm}$ 
2. Considering fork as a cantilever beam \& a uniform distributed load acting on the beam. Using material SAE 1030, Maximum allowable bending stress $=225 \mathrm{Mpa}$

By using Ansys software Figure 4, bending stress $=53.767$ Mpa

Allowable Stress > applied stress

Design is safe with factor of safety 2.62 \& total deformation $=2.003 \mathrm{~mm}$

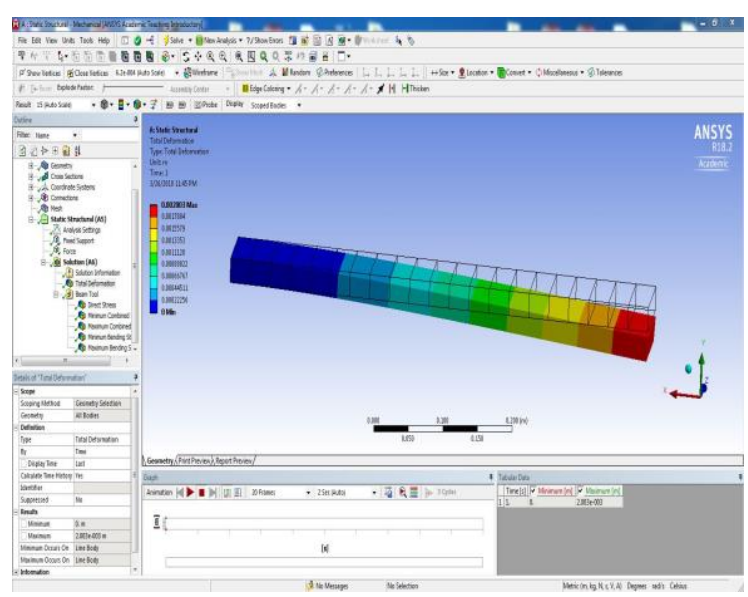

Figure 4. Stress analysis (ansys) of fork lift (cantilever beam $\&$ a uniform distributed load)

3. Considering point load on both fork (i.e. front side) and uniform distributed load at rear end of $180 \mathrm{~kg}$ ( i.e. $120 \mathrm{~kg}$ of battery \& counter weight and $60 \mathrm{~kg}$ as average weight of human driver).Using material SAE 1030, Maximum allowable bending stress $=225 \mathrm{Mpa}$

By using Ansys software Figure 5, bending stress = 4.66 Mpa Allowable Stress > applied stress

Therefore, Design is safe with factor of safety $48.28 \&$ total deformation $=0.031 \mathrm{~mm}$

\section{TESTING AND PERFORMANCE}

After the completion of manufacturing operations and assembly a trial run was taken and performance was satisfactorily completed. The load of $300 \mathrm{~kg}$ has been lifted up smoothly and placed at a height of $1.8 \mathrm{~m}$. The traveling speed of the forklift was about $15-20 \mathrm{~km} / \mathrm{hr}$ without load and 10 $15 \mathrm{~km} / \mathrm{hr}$ with load which varies according to the weight. As the chain block of capacity $1 / 5$ ton was attached to the lifting D.C. Motor the rated load to be lifted has been lifted in about $3 \mathrm{~min}$ in full height. The hoist speed remains same while moving downward direction.

\section{RESULT AND DISCUSSION}

The trial run of machine was carried out successfully. Adequacy of lifting and driving motor was confirmed. The fork lift was able to take the turns in narrow corner thank to its mall turning radius. All parts and components performed well and no failure was observed.

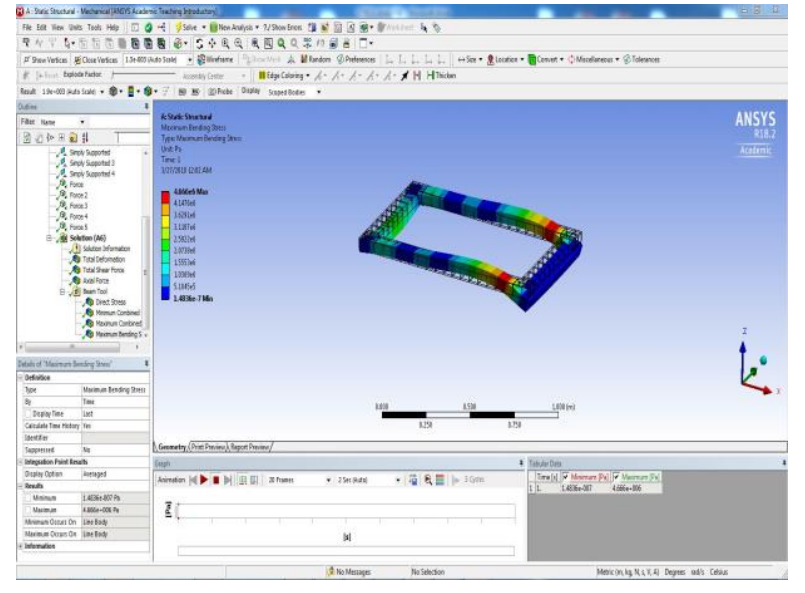

Figure 5. Stress analysis (ansys) of fork lift (point load on both fork (i.e. front side) and uniform distributed load )

\section{CONCLUSION}

The two wheel drive forklift is a mechatronics product $\&$ can be used in no. of industries. The design has proven capability to lift $300 \mathrm{~kg}$ up to $1.8 \mathrm{~m}$. Its control is easy due to electronics circuits developed. It is economical as compared to commercial fork lift available in market. It can be driven smoothly on any surface whether it is concrete floor or road.

\section{REFERENCES}

[1] Dr.R.N. Mall .( 2013):Automated Guided Vehicle, ISBN 2091 Journal, MMMEC, Gorakhpur.

[2] Kenneth B. Ackerman (2017):Forklifts and Other Mobile Equipment, Practical Handbook of Warehousing, Springer Nature,

[3] Dr.V.R.Gandhewar, (2018): Application of Forklift for Sensitive Material Handling",Volume 8 Issue No.4, International Journal of Engineering Science and Computing, April

[4] Rajat. R. Wade , (2018):Battery Operated 3 Wheel Drive Forklift for Industrial Warehouse “, International Journal for Scientific Research \& Development| Vol. 5, Issue 12, | ISSN (online): pp2321-0613

[5] J B Gupta , (2009) : Basic Electrical \& Electronics Engineering ,S. K. Kataria \& Sons.

[6] B L Thareja, A K Thareja Revised by S G Tarnekar (2005):A textbook of Electrical Technology, S Chand publishers.

[7] V B Bhandari (2007): Design Of Machine Elements, Tata McGraw-Hill Education.

[8] R S Khurmi, J.K Gupta (1996):A text book of Machine Design. Eurasia Publishing House.

[9] S S Rattan (2014):Theory Of Machines,McGraw-Hill Education (India) Private limited. 